\title{
Perencanaan dan implementasi perlindungan perempuan dan anak korban kekerasan di DIY (Studi pada P2TPA “RDU” DIY)
}

\author{
Yohanes Kristian Adiyuwana ${ }^{a^{*}}$ \\ ${ }^{a}$ Badan Pemberdayaan Perempuan Dan Masyarakat DIY, Yogyakarta, Indonesia
}

\section{INFORMASI ARTIKEL}

\section{Article history:}

Dikirim tanggal: 13 Februari 2016

Revisi pertama tanggal: 17 Februari 2016

Diterima tanggal: 20 Mei 2016

Tersedia online tanggal: 10 Juni 2016

\section{Keywords: planning, implementation,} victims of violence, women, children

\section{ABSTRACT}

Violence against women and children is deemed as violation of human right and could widely end up affected to the society. This research aims to examine planning of protection for women and children victims in BPPM Province of DIY, implementation of protection for women and children victims in P2TPA RDU Province of DIY, and factors of implementation of protection for women and children victims in P2TPA RDU Province of DIY. Qualitative research approach is used to explore what and how planning and implementation of women and children protection have been conducted. The findings show RKA planning of P2TPA RDU conforms rules of requirements of good planning according to Darwin's (2006), however it does not follow the rule of coordination and participation character. Planning of protection for women and children as violence victim has been implemented and ran well in general. Influenced factors for implementation of protection for women and children as violence victim in P2TPA RDU Provice of DIY, such as communication, resources, disposition, and structure of bureaucracy are running well although not optimum yet.

\section{INTISARI}

Kekerasan terhadap perempuan dan anak adalah termasuk pelanggaran terhadap HAM dan bisa mengakibatkan efek yang luas pada masyarakat secara umum. Tujuan dari penelitian ini adalah untuk mengetahui, menganalisis, dan juga mendeskripsikan: perencanaan perlindungan perempuan dan anak korban kekerasan di BPPM DIY; implementasi perlindungan perempuan dan anak korban kekerasan di P2TPA RDU DIY; faktor-faktor yang mempengaruhi implementasi perlindungan perempuan dan anak korban kekerasan di P2TPA RDU DIY. Penelitian kualitatif dilakukan untuk menelusuri apa dan bagaimana perencanaan dan pelaksanaan perlindungan wanita dan anak. Hasil dari penelitian ini adalah bahwa: Penyusunan RKA kegiatan P2TPA RDU, jika mengacu pada syarat perencanaan yang baik menurut Darwin (2006), maka penyusunan rencana sudah sesuai dengan kaidah-kaidah yang ada, tetapi masih kurang dalam hal koordinasi dan sifat partisipatori. Implementasi rencana perlindungan perempuan dan anak korban kekerasan di P2TPA RDU secara umum sudah berjalan dengan baik. Faktor-faktor yang mempengaruhi implementasi perlindungan perempuan dan anak korban kekerasan di P2TPA RDU DIY yaitu komunikasi, sumber daya, disposisi, dan struktur birokrasi sudah berjalan dengan baik walaupun belum optimal.

2016 FIA UB. All rights reserved. 


\section{Pendahuluan}

Dewasa ini, kekerasan terhadap perempuan dan anak banyak dibahas di media, baik cetak, maupun elektronik. Ditinjau dari perspektif individual maupun sosial, kekerasan terhadap perempuan dan anak dapat mengakibatkan efek ganda (multiplier effect). Bukan hanya psikologis dan kesehatan individu saja, tetapi juga akan berdampak pada kualitas kesehatan masyarakat pada umumnya. Sutrisminah (2012) dalam penelitiannya yang berjudul "Dampak Kekerasan Pada Istri Dalam Rumah Tangga Terhadap Kesehatan Reproduksi" memaparkan bahwa kekerasan terhadap perempuan/ istri sebagai korban mempunyai dampak yang meluas antara lain fisik, mental, yaitu stres, trauma, rasa percaya diri dan harga diri yang menurun, mengalami depresi, juga keinginan untuk bunuh diri. Dampaknya bagi anak korban kekerasan adalah anak akan mengalami depresi, berpotensi untuk hidup dengan kekerasan, perilaku kejam pada anak-anak akan lebih tinggi.

Tingginya angka kekerasan di DIY terlihat dari data penanganan kasus kekerasan yang ditangani oleh P2TPA "RDU" DIY dalam lima tahun terakhir. Jumlah kekerasan yang tercatat pada tahun 2010 sejumlah 126 kasus. Pada tahun 2011, terdapat 124 kasus yang ditangani. Di tahun 2012, angkanya meningkat menjadi 133 kasus. Pada tahun 2013, jumlah kasus yang ditangani berjumlah 142, dan pada tahun 2014 data yang masuk menunjukkan angka kekerasan yang ditangani berjumlah 120 kasus. Untuk mengoptimalkan perlindungan terhadap perempuan dan anak korban kekerasan di DIY, hendaknya tidak hanya bergantung pada satu sektor saja. Tetapi di sisi lain juga melibatkan banyak sektor yang terkait, sehingga kebutuhan korban dapat terpenuhi.

Menanggapi hal ini, Pemerintah Daerah DIY mengeluarkan beberapa produk hukum, diantaranya Peraturan Daerah DIY Nomor 3 tahun 2012 tentang Perlindungan Perempuan dan Anak Korban Kekerasan, Peraturan Gubernur DIY Nomor 66 tahun 2012 tentang Forum Perlindungan Korban Kekerasan, dan Peraturan Gubernur DIY Nomor 67 tahun 2012 tentang Organisasi Dan Tata Kerja Pusat Pelayanan Terpadu Perempuan \& Anak Korban Kekerasan "Rekso Dyah Utami". Dalam pengimplementasian di lapangan, Pemerintah Daerah DIY melalui Badan Pemberdayaan Perempuan dan Masyarakat (BPPM) DIY sebagai instansi di tingkat provinsi di DIY yang mengurusi masalah perlindungan perempuan dan anak, telah melaksanakan program dan kegiatan yang bertujuan menangani permasalahan kekerasan terhadap perempuan dan anak di DIY. Salah satu kegiatan tersebut adalah "Pelayanan Perlindungan Perempuan dan Anak Korban Kekerasan". Kegiatan ini melekat pada Sub Bidang Kualitas Hidup dan
Perlindungan Perempuan (KHPP), Bidang Perlindungan Hak-Hak Perempuan (PHP) di BPPM DIY. Pelaksana teknis kegiatan ini berupa adalah P2TPA "Rekso Dyah Utami". Jadi P2TPA "RDU" di sini berupa sebuah kegiatan, dan belum berbentuk UPTD.

Berdasarkan sejumlah keterangan di atas, maka rumusan masalah yang diambil penulis dalam jurnal ilmiah ini adalah, pertama, bagaimana perencanaan perlindungan perempuan dan anak di BPPM DIY? Kedua, bagaimana implementasi rencana perlindungan perempuan dan anak korban kekerasan di P2TPA "RDU" DIY? Ketiga, apa dan bagaimanakah faktorfaktor yang mempengaruhi implementasi perlindungan perempuan dan anak korban kekerasan di P2TPA "RDU" DIY?

\section{Teori}

\subsection{Konsep Perencanaan}

Terdapat banyak definisi tentang perencanaan karena memang banyak kegiatan manusia dalam kehidupan sehari-hari banyak melibatkan perencanaan di dalamnya. Seseorang yang menyusun rencana, berarti menetapkan langkah-langkah yang akan diambil kedepan ke dalam pikirannya, sehingga akan menghasilkan suatu hasil tertentu yang sudah menjadi tujuan awalnya.

Menurut Sitanggang (1999) perencanaan adalah alat atau unsur manajemen dalam upaya menggerakkan dan mengarahkan organisasi dan bagian-bagiannya mencapai tujuan yang ditentukan. Perencanaan merupakan salah satu proses yang penting dari serangkaian fungsi manajemen, karena tanpa perencanaan fungsi-fungsi lain pengorganisasian, pengarahan dan pengontrolan tak akan dapat berjalan. Perencanaan adalah dimana proses manajemen memutuskan tujuan dan cara mencapainya. Sebelum pimpinan organisasi dapat mengatur, mengarahkan atau mengawasi, mereka harus membuat rencana yang memberikan tujuan dan arah organisasi.

Friedman dalam Tarigan (2012) menambahkan bahwa dalam memformulasikan suatu perencanaan diperlukan pemikiran yang mendalam dan melibatkan banyak aktor/ pihak, sehingga rencana yang dihasilkan dapat diterima oleh masyarakat luas. Dengan demikian, perencanaan memerlukan peran aktif dan aspirasi dari pihak stakeholder secara keseluruhan. Tujuannya adalah agar rencana yang dihasilkan bisa lebih memuaskan banyak pihak.

Dalam penetapan tujuan dan terutama dalam cara pencapaian tujuan itu, tiga (3) unsur penting daripada perencanaan yang meminta perhatian, menurut Tjokroamidjojo (1995) adalah: (1) Perlunya koordinasi; (2) Konsistensi antara berbagai variabel sosial ekonomi suatu masyarakat; dan (3) Penetapan skala prioritas. 
Mendalami tentang perencanaan, maka kita akan mengenal berbagai macam perencanaan menurut klasifikasinya masing-masing. Sitanggang (1999) membuat tingkatan perencanaan berdasarkan jenjang manajemen atau tingkat pertanggung jawaban manajemen menjadi tiga macam, yaitu: (1) Perencanaan untuk tugas Top Management (Perencanaan Strategis) yakni perencanaan umum yang sifatnya jangka panjang dan di dalamnya visi dan misi organisasi, serta tujuantujuan pokok yang hendak dicapai organisasi secara keseluruhan. Yang bertanggung jawab adalah manajemen tingkat atas; (2) Perencanaan bagi Middle Level Management (Perencanaan Administrasi atau Perencanaan Taktis) yakni rencana yang menjabarkan Rencana Strategis diatas ke dalam perincian rencana yang lebih lanjut tentang bagian-bagian, sub sektor yang menjadi bidang tugas unit organisasi, membuat ketentuan-ketentuan tentang prosedur dan pedoman teknis pelaksanaan. Yang bertanggung jawab disini adalah manajemen tingkat menengah; (3) Perencanaan bagi Lower Level Management (Perencanaan Operasional) merupakan perencanaan mengenai teknis pelaksanaan dan prosedur, serta cara-cara penggunaan sumber daya. Yang bertanggung jawab pada tingkatan ini adalah manajemen tingkat menengah kebawah/ manajemen operasional.

\subsection{Konsep Implementasi}

Implementasi dianggap penting dalam proses perencanaan pembangunan karena jika tidak diimplementasikan dengan baik maka pembangunan tidak akan berhasil dilaksanakan. Tujuan dari perencanaan bukanlah untuk menghasilkan rencana, melainkan untuk memperoleh hasil-hasil yang sifatnya praktis. Untuk itu, apabila suatu program sudah dibuat, maka program tersebut harus dilakukan oleh para aparat yang berkepentingan.

Pressman \& Wildavsky dalam Conyers \& Hills (1990) mendefinisikan implementasi sebagai "as a process of interaction between the setting of goals and action geared to achieving them". Bahwa implementasi adalah proses interaksi antara penetapan tujuan dan tindakan yang diarahkan untuk mencapai tujuan. Conyers \& Hills (1990) berpendapat bahwa meskipun kegiatan perencanaan terpisah dengan implementasi, tapi pola pikir diantara keduanya harus seiring, karena keduanya terletak dalam sebuah siklus 'Planning Process' yang tidak dapat dipisahkan.

Pengertian implementasi menurut Higgins dalam Salusu (2003) adalah rangkuman dari berbagai kegiatan, yang di dalamnya, sumber daya manusia menggunakan sumber daya lain untuk mencapai sasaran dari strategi. Kegiatan itu menyentuh semua jajaran manajemen, mulai dari manajemen puncak sampai pada karyawan lini paling bawah. Singkatnya, menurut Salusu, implementasi adalah satu proses yang terarah dan terkoordinasi, melibatkan banyak sumber daya.

Implementasi sebagai suatu proses tindakan Administrasi dan Politik. Pandangan ini sejalan dengan pendapat Cleaves dalam buku yang ditulis oleh Wahab (2008), yang secara tegas menyebutkan bahwa implementasi itu mencakup: "a process of moving toward a policy objective by means of administrative and political steps". Secara garis besar, beliau mengatakan bahwa fungsi implementasi itu ialah untuk membentuk suatu hubungan yang memungkinkan tujuan-tujuan ataupun sasaran-sasaran diwujudkan sebagai outcome hasil akhir kegiatan yang dilakukan oleh pemerintah".

Terdapat banyak faktor yang akan mempengaruhi tingkat keberhasilan suatu implementasi. Faktor-faktor tersebut akan mempengaruhi satu dengan yang lainnya. Edwards III dalam Subarsono (2011) menyebutkan bahwa faktor-faktor yang mempengaruhi implementasi ada empat, yaitu: (1) Komunikasi; (2) Sumber daya; (3) Disposisi; (4) Struktur birokrasi.

\subsection{Perlindungan Perempuan dan Anak Korban Kekerasan}

Pengertian perlindungan menurut Undang-Undang Nomor 23 Tahun 2004 tentang Penghapusan Kekerasan Dalam Rumah Tangga adalah segala upaya yang ditujukan untuk memberikan rasa aman kepada korban yang dilakukan oleh pihak keluarga, advokat, lembaga sosial, kepolisian, kejaksaan, pengadilan, atau pihak lainnya baik sementara maupun berdasarkan penetapan pengadilan. Sedangkan pengertian perlindungan perempuan dan anak menurut Peraturan Presiden Republik Indonesia Nomor 18 Tahun 2014 tentang Perlindungan dan Pemberdayaan Perempuan dan Anak Dalam Konflik Sosial adalah upaya pencegahan dan penanganan dari segala bentuk tindak kekerasan dan pelanggaran hak asasi perempuan dan anak, serta memberikan layanan kebutuhan dasar dan spesifik perempuan dan anak dalam penanganan konflik sebagai bagian yang tidak terpisahkan dari kegiatan penanganan konflik.

Korban adalah mereka yang menderita jasmaniah dan rohaniah sebagai akibat tindakan orang lain yang mencari pemenuhan kepentingan diri sendiri atau orang lain yang bertentangan dengan kepentingan dan hak asasi yang menderita (Gosita, 1993). Korban juga diartikan sebagai orang-orang yang baik secara individual maupun kolektif telah menderita kerugian, termasuk kerugian fisik atau mental, emosional, ekonomi atau gangguan substansial terhadap hakhaknya yang fundamental, melalui perbuatan atau komisi yang melanggar hukum pidana di masingmasing negara, termasuk penyalahgunaan kekuasaan (Muladi, 2005). 
Secara etimologi, kekerasan berasal dari bahasa latin violence yaitu gabungan kata "vis" (daya, kekuatan) dan "latus" (membawa) yang kemudian diterjemahkan membawa kekuatan (Windu, 1971). Pengertian ini dalam Kamus Umum Bahasa Indonesia diartikan sebagai sifat atau hal yang keras; kekuatan; paksaan, sedangkan paksaan berarti tekanan, desakan yang keras. Kemudian secara terminologi, pengertian kekerasan adalah suatu keadaan dan sifat menghancurkan kehidupan manusia. Manusia sebagai makhluk yang berakal budi dan mulia menjadi terperosok pada sifat-sifat kebinatangan. Merusak, menekan, memeras, memperkosa, menteror, mencuri, membunuh, dan memusnahkan merupakan tindakan yang menodai dan menghancurkan kemuliaan manusia sebagai makhluk Tuhan (Nashir, 1999).

Bentuk dari kekerasan terhadap anak bisa bermacam-macam. Menurut Mufidah dkk (2006) terdapat tujuh (7) bentuk kekerasan yang lazim ditemukan, diantaranya adalah sebagai berikut: (1) Kekerasan dalam bentuk fisik seperti pemukulan, penganiayaan berat yang menyebabkan jatuh sakit, bahkan kematian; (2) Kekerasan psikis seperti ancaman, pelecehan, sikap kurang menyenangkan yang menyebabkan rasa takut, rendah diri, trauma, depresi atau gila; (3) Kekerasan ekonomi, misalnya menelantarkan anak; (4) Kekerasan seksual berbentuk pelecehan seksual, pencabulan dan pemerkosaan; (5) Eksploitasi kerja dan bentuk pekerjaan terburuk untuk anak; (6) Eksploitasi seksual komersial anak; dan (7)Trafficking (perdagangan) anak.

\section{Metode Penelitian}

Penelitian yang digunakan pada penulisan jurnal ilmiah ini menggunakan pendekatan kualitatif. Lokasi yang menjadi objek penelitian ini adalah di kantor BPPM DIY dan kantor P2TPA "RDU" DIY. Yang menjadi fokus dalam penelitian ini adalah: (1) Perencanaan perlindungan perempuan dan anak di BPPM DIY; (2) Implementasi rencana perlindungan perempuan dan anak di P2TPA "RDU" DIY, yang meliputi jenis layanan dan mekanisme pelayanan; (3).Faktor-faktor yang mempengaruhi implementasi perlindungan perempuan dan anak korban kekerasan di P2TPA "RDU" DIY, yang meliputi: komunikasi, sumber daya, disposisi, struktur birokrasi.

Sumber datanya berupa data primer, yaitu berupa wawancara, pengamatan langsung di lapangan, dokumentasi. Selain itu juga data sekunder yang diperoleh dari literatur artikel, serta situs di internet yang berkenaan dengan penelitian yang dilakukan. Dalam jurnal ilmiah ini, penulis mempergunakan analisis data model interaktif menurut Miles, Huberman, \& Saldana (2014) yang langkah-langkahnya berupa: (1). Pengumpulan data; (2). Kondensasi data; (3). Penyajian data; (4). Penarikan kesimpulan.

\section{Hasil Penelitian dan Pembahasan}

Pelayanan di P2TPA "RDU" DIY bersifat berjejaring dan dibiayai oleh pemerintah dalam operasional kegiatannya. Sifat pelayanannya melibatkan institusi lain, berupa sebuah forum, yaitu Forum Penanganan Korban Kekerasan (FPKK) dalam penanganan terhadap korban kekerasan perempuan dan anak. Hal ini berarti bahwa dalam melaksanakan tupoksinya, juga terdapat unsur governance di dalamnya. Menurut Sedarmayanti (2004) bahwa unsurunsur dalam kepemerintahan (governance stakeholders) ada tiga, yakni unsur pemerintah, swasta, dan masyarakat madani. Dalam hal ini, LBH APIK (Asosiasi Perempuan Indonesia untuk Keadilan), LSPPA (Lembaga Studi Pengembangan Perempuan dan Anak), Yayasan Sayap Ibu Cabang DIY, LSM Rifka Annisa adalah contoh pihak di luar pemerintah yang terdaftar menjadi anggota FPKK DIY. Walaupun demikian, pihak pemerintah tetaplah berada di garda terdepan dalam forum bersama ini. Dengan adanya keikutsertaan dan koordinasi yang baik antara pihak pemerintah dengan pihak di luar pemerintah, diharapkan misi penanganan terhadap perempuan dan anak korban kekerasan di DIY berjalan dengan lebih efektif.

\subsection{Perencanaan Perlindungan Perempuan dan anak di BPPM DIY}

Syarat-syarat perencanaan yang baik seperti dikemukakan oleh Darwin (2006) antara lain harus mencakup adanya beberapa unsur, yaitu: (1).didasari dengan tujuan pembangunan yang jelas; (2).konsisten dan realistis; (3).pengawasan yang terus-menerus; (4).mencakup aspek fisik dan pembiayaan; (5).mempunyai koordinasi yang baik; (6).adaptif terhadap perubahan eksternal dan ketidakpastian; (7).bersifat partisipatori.

Pada unsur (1) yaitu didasari dengan tujuan pembangunan yang jelas, target dari perencanaan perlindungan perempuan dan anak di DIY adalah melayani dan menangani korban kekerasan yang melapor. Selain itu juga menurunkan angka kekerasan perempuan dan anak di DIY. Hal ini terlihat dari indikator keluaran Dokumen Pelaksanaan Perubahan Anggaran (DPPA) kegiatan "Pelayanan Perlindungan Perempuan dan Anak Korban Kekerasan", yaitu fasilitasi terhadap perempuan dan anak korban kekerasan, pelayanan TESA terhadap Anak Korban Kekerasan. Sedangkan indikator tercapainya program adalah rasio kekerasan terhadap perempuan dan anak yang dari tahun ke tahun sesuai dengan Renstra SKPD angka targetnya terus menurun.

Arah dari perencanaan perlindungan perempuan dan anak di BPPM DIY sebaiknya mengacu pada 
perundang-undangan di tingkat yang lebih tinggi, seperti RPJMD DIY. Dalam hal ini, perencanaan perlindungan perempuan dan anak di BPPM DIY sudah bertujuan untuk mendukung dan berkontribusi pada tercapainya target-target perlindungan perempuan dan anak, baik di tingkat nasional maupun daerah.

Dalam hal perencanaan yang konsisten dan realistis (2), konsistensi perencanaan perlindungan perempuan dan anak korban kekerasan di DIY terlihat dari jumlah anggaran kegiatan "Pelayanan Perlindungan Perempuan dan Anak Korban Kekerasan". Dalam tiga tahun terakhir (2012-2014), pagu untuk kegiatan ini adalah tigaratus juta rupiah, tigaratus sepuluh juta rupiah, dan tigaratus limapuluh juta rupiah. Besarnya pagu anggaran dalam tiga tahun terakhir menunjukkan tidak ada pengurangan dana, tetapi cenderung mengalami kenaikan guna menyesuaikan terhadap besarnya inflasi tahunan dan mengantisipasi kenaikan angka korban pelapor. Adanya konsistensi dukungan dana dari pemerintah sangat membantu mewujudkan penanganan korban kekerasan di P2TPA "RDU" secara lebih maksimal.

Sifat realistis perencanaan terlihat dari dokumen perencanaan yang ada (RKA, DPA, DPPA) yang di dalamnya sudah memuat pagu anggaran yang tersedia berikut peruntukan penggunaannya. Di dalamnya sudah tercover keperluan-keperluan yang dibutuhkan selama satu tahun. Dengan pagu anggaran yang tersedia dan dengan dokumen perencanaan yang ada, dimungkinkan semua korban pelapor selama satu tahun anggaran dapat tertangani dengan baik. Bila terdapat kekurangan atau kelebihan, dapat diajukan penambahan atau pengurangan pagu anggaran di pertengahan tahun.

Pengawasan yang terus-menerus merupakan persyaratan perencanaan yang baik ke (3). Pengawasan dilakukan oleh pihak internal maupun eksternal SKPD. Pengawasan internal SKPD dilakukan oleh Subbag Program, data, dan TI yang juga mengampu tupoksi bidang perencanaan di BPPM DIY. Perencanaan yang disusun oleh sub bidang teknis pengampu kegiatan, akan dikonsultasikan terlebih dahulu ke Subbag Program. Apabila masih terdapat hal-hal yang harus diperbaiki, baik dalam hal format penulisan ataupun substansi yang tidak sesuai dengan ketentuan, maka akan dikembalikan ke perencana sub bidang untuk diperbaiki, sampai perencanaan yang disusun sesuai.

Pengawasan berikutnya dari Tim Anggaran Pemerintah Daerah (TAPD) DIY. Perencanaan dari sub bidang teknis yang masuk ke Subbag Program BPPM, akan dibahas bersama dalam sebuah rapat antara pihak sub bidang, Subbag Program, didampingi oleh sekretaris/Kepala BPPM, dengan TAPD. Di sini biasanya masih terdapat perbaikan-perbaikan yang diusulkan oleh TAPD. Hal ini bisa diakibatkan oleh banyak hal, diantaranya adalah: kurang sesuai dengan Standar Harga Barang dan Jasa (SHBJ), ASB (Analisis
Standar Belanja). Bisa juga karena kondisi keuangan daerah yang tidak memungkinkan dan harus dibagi dengan urusan pemerintahan lain yang dipandang lebih prioritas untuk dilaksanakan terlebih dahulu.

Unsur pengawasan yang lain adalah DPRD, yang merupakan wujud perwakilan rakyat dalam pemerintahan. Setelah perencanaan disetujui oleh TAPD, akan diajukan dalam sebuah rapat bersama pembahasan anggaran yang melibatkan pihak legislatif, hingga terjadi kesepakatan antar pihak. Dari sini hasil kesepakatan tersebut dibawa ke pusat untuk dicermati kembali. Di sana masih mungkin terjadi perubahan lagi. Hal ini bisa dikarenakan program/ kegiatan yang dipandang sudah tidak relevan lagi, terdapat penambahan kegiatan yang dipandang perlu, atau bisa juga dilakukan efisiensi di dalamnya. Setelah mendapatkan persetujuan dari pihak pemerintah pusat, maka kegiatan "Pelayanan Perlindungan Perempuan dan Anak Korban Kekerasan", bersama dengan kegiatan lain dari semua SKPD di DIY akan disahkan oleh Gubernur sebagai Kepala Daerah dan DPRD.

Syarat perencanaan baik yang ke (4), yaitu mencakup aspek fisik dan pembiayaan, dalam hal ini sudah terangkum di dalam dokumen perencanaan, RKA kegiaatan. Disana tercantum penggunaan anggaran untuk belanja apa saja, termasuk kuantitas barang/jasa, berikut harganya. Jadi aspek fisik dan pembiayaan sudah tercantum pada dokumen perencanaan yang ada. Pembiayaan yang tercantum dalam dokumen perencanaan SKPD ini harus mengacu pada standar yang ada, yang sudah ditetapkan terlebih dahulu oleh Biro Organisasi Setda DIY. Standar-standar tersebut adalah SHBJ (Standar Harga Barang dan Jasa) serta ASB (Analisis Standar Belanja) yang terdiri dari SBU (Standar Belanja Umum) dan SBK (Standar Belanja Khusus).

Memasuki syarat yang ke (5) perencanaan yang baik adalah mempunyai koordinasi yang baik. Koordinasi yang dimaksudkan di sini adalah diantara stake holder perlindungan perempuan dan anak di DIY. Kegiatan di P2TPA RDU, perencanaannya disusun oleh BPPM DIY, pada di Sub bidang KHPP (Kualitas Hidup dan Perlindungan Perempuan) Bidang PHP (Perlindungan Hak-Hak Perempuan). Dalam tingkatan ke atas, perencanaan perlindungan perempuan dan anak yang dilakukan sudah berkoordinasi dengan bagian perencanaan instansi, yaitu Subbag Program, Data, dan TI, yang juga secara rutin sudah menjalin komunikasi dan koordinasi dengan anggota TAPD (Tim Anggaran Pemerintah Daerah) DIY.

Dalam sebuah wawancara dengan salah satu pengelola P2TPA "RDU", dan dengan Kepala Sub Bidang KHPP, didapatkan sebuah keterangan bahwa dalam penyusunan rencana kegiatan "Pelayanan Perlindungan Perempuan dan Anak Korban Kekerasan", tidak terdapat rapat resmi antara pihak Sub Bidang 
KHPP dengan pengelola P2TPA "RDU". Hal ini menunjukkan bahwa dalam tingkatan ke bawah, perencanaan belum sepenuhnya terkoordinasi dengan baik. Kebutuhan yang ada di lapangan belum dicatat berdasarkan konsolidasi dan koordinasi dengan pihak implementor di lapangan yaitu pengurus P2TPA "RDU". Komunikasi hanya dilakukan melalui percakapan dan forum tidak resmi saja. Akibatnya dokumen perencanaan yang menjadi pedoman pelaksanaan kegiatan belum dapat memuaskan semua pihak, khususnya pihak pengelola P2TPA "RDU".

Syarat perencanaan yang baik selanjutnya (6), adaptif terhadap perubahan eksternal dan ketidakpastian, hal ini terkait dengan salah satu pendapat dari Tjokroamidjojo (1995), bahwa salah satu alasan untuk melakukan perencanaan adalah dengan adanya perencanaan, maka bisa diperkirakan kejadian di masa yang akan datang. Perkiraan itu bisa berupa potensi, hambatan, atau resiko dalam melaksanakan kegiatan itu. Apabila dalam pelaksanaan kegiatan masih terdapat hal yang terjadi diluar perencanaan, dan membutuhkan anggaran lebih, diantisipasi dengan pengajuan perubahan anggaran (penambahan/ pengurangan) dari pagu awal yang dapat diusulkan pada pertengahan tahun anggaran, yang diusulkan kepada TAPD melalui Subbag. Program, Data, dan TI BPPM dengan mencantumkan besarnya anggaran yang diminta, disertai alasan yang jelas. Disetujui atau tidaknya permohonan tersebut bisa tergantung dari urgensi kegiatan, besarnya sisa kas daerah, dan prioritas pembangunan daerah yang ada.

Syarat terakhir (7) perencanaan yang baik adalah bersifat partisipatori. Partisipasi bisa berasal dari pihak internal maupun eksternal BPPM DIY. Dalam hal ini, partisipasi sudah ada dari internal organisasi, dimana pihak sub bidang teknis sudah berkomunikasi dan mendapatkan masukan dari bagian perencanaan instansi (Subbag Program, Data, dan TI). Di sisi lain, belum terdapat partisipasi yang baik dari dari pengelola P2TPA "RDU" maupun dari pihak lain dalam bentuk rapat formal untuk perencanaan kegiatan. Hal ini sesuai dengan hasil wawancara dengan pengelola P2TPA "RDU" dan Kasubbid KHPP BPPM DIY.

\subsection{Implementasi Rencana Perlindungan Perempuan dan Anak Korban Kekerasan di P2TPA "RDU" $D I Y$}

Menurut Pergub DIY Nomor 67 tahun, disebutkan bahwa di P2TPA "RDU" seharusnya terdapat lima bidang layanan. Bidang layanan tersebut beserta tugasnya adalah:

(1). Bidang Layanan Pengaduan, menurut Pasal 12 Peraturan Gubernur DIY Nomor 67 tahun 2012 memiliki tugas:

(a). Memberikan konseling pada korban; (b). Melakukan koordinasi dan rujukan ke layanan lanjutan dan pihak terkait;

(c). Melakukan administrasi proses pengaduan.

(2). Bidang Layanan Kesehatan, menurut Pasal 13 Peraturan Gubernur DIY Nomor 67 tahun 2012 memiliki tugas:

(a). Memberikan pertolongan pertama terhadap korban;

(b). Memfasilitasi konsultasi kepada dokter ahli atau melakukan rujukan;

(c). Membuat laporan kasus.

(3). Bidang Layanan Rehabilitasi Sosial, menurut Pasal 14 Peraturan Gubernur DIY Nomor 67 tahun 2012 memiliki tugas:

(a). Melakukan pendampingan selama proses penanganan kasus;

(b). Memberikan pelayanan berupa konseling;

(4). Bidang Layanan Pemulangan dan Reintegrasi Sosial, menurut Pasal 15 Peraturan Gubernur DIY Nomor 67 tahun 2012 memiliki tugas:

(a). Berkoordinasi dengan stakeholder yang bersangkutan saat korban dipulangkan;

(b). Melakukan pembuatan pelaporan dalam proses pendampingan dalam tahapan ini;

(c). Korban dipantau minimal selama tiga bulan ke depan.

(5). Bidang Layanan Bantuan Hukum, menurut Pasal 16 Peraturan Gubernur DIY Nomor 67 tahun 2012 memiliki tugas:

(a). Memberikan pelayanan konsultasi hukum, pendampingan, dan pembelaan hukum;

(b). Melakukan koordinasi dan rujukan ke layanan lanjutan dan pihak terkait;

Mekanisme alur pelayanan di P2TPA "RDU" telah diatur dalam Pergub DIY Nomor 67 tahun 2012. Hal tersebut lebih khususnya diatur dalam Pasal 32 sampai dengan Pasal 41.

Dalam pasal 32, disebutkan bahwa korban dapat menyampaikan kasus kekerasan yang terjadi kepadanya dengan cara datang sendiri, diantar orang lain, rujukan anggota FPKK, atau melaporkan kasusnya melalui telepon dan dilanjutkan dengan tatap muka. Untuk anak korban kekerasan didampingi oleh keluarga atau tetangga korban, atau jika tidak ada pendamping, bisa disediakan oleh pihak P2TPA "RDU".

Pasal 33 menuliskan bahwa korban harus mengisi formulir baik secara langsung ataupun dituliskan oleh pihak keluarga yang ikut mendampingi melaporkan atau dari pihak P2TPA "RDU". Setelah formulir diisi, petugas memberikan pendampingan awal pada korban sesuai dengan kebutuhannya. Selain itu, petugas "RDU" membuat rencana intervensi lanjutan berdasarkan pada isian formulir dari korban. Layanan yang dimaksud dapat berupa: layanan rehabilitasi kesehatan, layanan rehabilitasi sosial, layanan bantuan hukum, layanan pemulangan dan reintegrasi sosial. 
Formulir yang diisi korban berisi mengenai datadata korban, pelaku, garis besar cerita kasus yang menimpa korban. Dengan formulir ini, didapatkan gambaran umum mengenai kasus yang akan ditangani oleh pengelola P2TPA "RDU" sehingga mempermudah mereka dalam melakukan diagnosa, dan menentukan intervensi penanganan yang sesuai dengan kebutuhan korban.

Sifat penanganan terhadap korban kekerasan yang berjejaring ditunjukkan pada pasal 40, yang berbunyi: bahwa dalam hal pelayanan kepada korban tidak tersedia, P2TPA "RDU" dapat melakukan rujukan pelayanan ke lembaga pelayanan lainnya. Dalam hal ini, P2TPA "RDU" tetap bertanggung jawab terhadap keseluruhan proses rujukan pelayanan yang diperlukan bagi korban. Dalam pasal 41 ditambahkan, untuk meningkatkan kualitas pelayanan, P2TPA "RDU" dalam melaksanakan tugas secara fungsional dapat mengadakan kerjasama dengan instansi pelayanan pemerintah dan non pemerintah terkait, sesuai dengan ketentuan peraturan perundang-undangan.

Sifat berjejaringnya penanganan terhadap korban kekerasan di DIY ini sesuai dengan pendapat dari Subarsono (2011), yang mengatakan bahwa pada dasarnya dalam berbagai sistem politik, kebijakan publik diimplementasikan oleh badan-badan pemerintah, dimana badan pemerintah itu mampu membawa dampak yang baik untuk warganya. Implementasi pada dasarnya mempunyai kerumitan, yang dapat ditunjukkan dengan banyaknya unit organisasi yang terlibat di dalamnya. Dari masingmasing variabel yang ada, dapat berinteraksi satu dengan yang lainnya.

Berdasarkan hasil wawancara salah satu konselor P2TPA "RDU", bahwa fungsi dari pelayanan yang dilakukan oleh rohaniawan di Bidang Layanan Rehabilitasi Sosial, diantaranya adalah mencoba memberikan pengertian kepada korban apabila kasus kekerasan yang terjadi masih ada kemungkinan untuk tidak diteruskan melalui jalur hukum. Sebab jika suatu kasus sudah sampai ke ranah hukum, kecenderungannya akan sulit untuk diperbaiki kembali hubungan rumah tangganya.

Hasil wawancara yang dilakukan dengan konselor lain di bidang hukum, mengindikasikan pentingnya konseling bidang hukum untuk mengadvokasi korban. Hal ini terjadi karena kebanyakan masyarakat kita memang buta akan hukum. Untuk itu di P2TPA "RDU" dipandang perlu untuk memberikan layanan konseling bidang hukum kepada korban kekerasan

Konseling bidang hukum sangat membantu pelaku juga, terutama bagi mereka yang buta hukum, untuk memberikan pemahaman mengenai akibat-akibat hukum yang ditimbulkan dari suatu tindakan pelanggaran hukum, yang dalam hal ini adalah kekerasan. Selain itu konselor hukum juga memberikan gambaran jika ternyata kasus yang dihadapi klien harus diteruskan ke ranah hukum. Apa kemungkinan yang akan terjadi, kerugiannya apa, dan lain sebagainya. Dengan pemahaman ini, diharapkan di kemudian hari perbuatan-perbuatan pelaku di kemudian hari bisa lebih terkontrol agar tidak lagi menyakiti korban.

Dari wawancara dengan konselor Bidang Layanan Pemulangan dan Reintegrasi Sosial, diperoleh keterangan bahwa pengelola P2TPA "RDU" berkoordinasi secara internal untuk menentukan, apakah klien membutuhkan pelatihan (agar keterampilannya meningkat), ataukah bantuan lain yang berupa tambahan modal usaha agar bisa lebih mandiri di kemudian hari. Apabila disimpulkan (bahwa klien) membutuhkan, maka pengelola "RDU" akan berkoordinasi dengan stakeholder lain (FPKK DIY), misalnya Dinas Sosial atau Disnakertrans (DIY) agar memberikan bantuan yang sesuai dengan kebutuhan korban. Dengan dibekali oleh keterampilan yang lebih baik atapun modal tambahan untuk mengembangkan usahanya, maka klien akan diantar oleh bidang pemulangan dan reintegrasi sosial kembali ke tengah-tengah masyarakat.

Disinilah klien sebagai korban tindak kekerasan diberdayakan agar menjadi lebih mandiri dan diharapkan di kemudian hari tidak terulang menjadi korban kekerasan lagi. Hal ini juga sesuai dengan tupoksi BPPM DIY, dimana selain berfungsi sebagai instansi tingkat provinsi yang berada di garis depan dalam hal perlindungan terhadap perempuan dan anak korban kekerasan, juga untuk memberdayakan kaum perempuan agar lebih mandiri dan berperan dalam pembangunan di masyarakat.

Fungsi yang diterangkan diatas, sesuai dengan pengertian pemberdayaan masyarakat menurut Suhendra (2006), yang memandang bahwa pemberdayaan masyarakat adalah pembangunan perekonomian masyarakat, dan kemudian dikembangkan, yang pengembangannya mendasarkan pada nilai-nilai yang berkembang di masyarakat. Dalam konsep ini terdapat sebuah paradigma baru yang lebih membawa penekanan pada peran serta masyarakat kesinambungan serta fokus pembangunan pada manusia. Konsep pemberdayaan masyarakat merupakan salah satu alternatif pembangunan, dimana paradigma pembangunan nasional dirubah menjadi pendekatan yang lebih partisipatif.

Pembiayaan dalam proses penanganan kasus di P2TPA "RDU" DIY kepada para korban dibebankan pada APBD DIY atau bersifat gratis untuk korban. Biayadi sini meliputi penjemputan ke tempat asal korban, biaya hidup selama tinggal di semi shelter ataupun di shelter, biaya untuk semua jenis konseling, bantuan hukum dan rumah sakit. Kecuali klien berasal dari golongan mampu dan menghendaki perawatan di Rumah Sakit sesuai dengan keinginannya, ataupun saat ia membutuhkan bantuan hukum dan sudah menyewa 
pengacara sendiri yang lebih dipercaya. Sedangkan untuk klien dari golongan tidak mampu, maka seluruh biaya, termasuk biaya rumah sakit dan bantuan hukum akan diberikan secara gratis, dengan dibuatkan Surat Keterangan Tidak Mampu (SKTM) yang nantinya akan dibayarkan oleh Bapeljamkesos.

Hal ini sesuai dengan yang dikemukakan oleh Institute of Governance (1996), sebagaimana dikutip oleh Nisjar dalam Sedarmayanti (2004) yang menuliskan bahwa untuk menciptakan administrasi publik yang mengandung unsur sistem koperasi dan pendekatan pelayanan publik yang relevan bagi masyarakat, maka dapat ditempuh dengan menciptakan beberapa hal, yang salah satunya adalah adanya pelayanan administrasi publik yang berorientasi kepada masyarakat yang dilayani, inklusif (mencerminkan layanan yang mencakup secara merata seluruh masyarakat bangsa yang bersangkutan, tanpa ada perkecualian), suatu sistem administrasi publik yang profesional, terjangkau, merata dan adil, serta mengutamakan kepentingan masyarakat dalam melakukan pelayanan.

Kaitannya dalam hal implementasi kegiatan, penjelasan yang diuraikan diatas sejalan dengan pendapat Cleaves dalam buku yang ditulis oleh Wahab (2008), yang menyebutkan bahwa implementasi itu mencakup: "a process of moving toward a policy objective by means of administrative and political steps". Secara garis besar, beliau mengatakan bahwa fungsi implementasi ialah untuk membentuk suatu hubungan yang memungkinkan tujuan-tujuan ataupun sasaran-sasaran diwujudkan sebagai outcome hasil akhir kegiatan yang dilakukan oleh pemerintah". Dalam hal ini implementasi perlindungan perempuan dan anak korban kekerasan di P2TPA "RDU" berfungsi untuk mencapai tujuan akhir dari kegiatan "Pelayanan Perlindungan Perempuan dan Anak Korban Kekerasan", agar semua korban kekerasan yang melapor di P2TPA "RDU" dapat terlayani dengan baik, sesuai dengan kebutuhannya.

Berdasarkan serangkaian keterangan diatas, didapatkan informasi bahwa mekanisme pelayanan yang ada di P2TPA "RDU" sudah mengacu pada Pergub DIY Nomor 67 tahun. Untuk mekanisme pelayanannya juga tidak berbelit dan sudah cukup efektif, serta berorientasi kepada kepentingan pelanggan, karena semua jenis layanan berada pada satu atap di kantor P2TPA "RDU" untuk jenis pelayanan tahap awal pada korban. Korban baru dirujuk ke anggota forum (FPKK) yang lain bila memang dirasa membutuhkan jenis pelayanan lanjutan, seperti halnya visum di Rumah Sakit. Hambatan dalam pelayanan muncul ketika korban melapor dan terkadang menunggu konselor yang dibutuhkan datang terlebih dahulu, karena selain sebagai konselor di P2TPA "RDU", pengelola juga punya profesi lain.

\subsection{Faktor-Faktor Yang Mempengaruhi Implementasi Perlindungan Perempuan dan Anak Korban Kekerasan di P2TPA "RDU DIY}

Dalam implementasi kegiatan perlindungan perempuan dan anak korban kekerasan di P2TPA "RDU", terdapat banyak faktor yang mempengaruhi tingkat keberhasilan pelaksanaannya di lapangan. Faktor-faktor tersebut akan mempengaruhi antara satu dengan yang lainnya. Menurut Edwards III dalam Subarsono (2011) faktor-faktor yang mempengaruhi implementasi tersebut ada empat macam yaitu: Komunikasi, Sumber Daya, Disposisi, dan Struktur Birokrasi.

\section{a) Komunikasi}

Komunikasi yang ada, terlihat dari laporan pertanggung jawaban keuangan kegiatan, bahwa agar LPJ diterima, maka pembelanjaan yang dilaporkan harus sesuai dengan dokumen perencanaan dan nilai SHBJ yang ada. Untuk terciptanya pengertian dari pihak pengelola P2TPA "RDU" tentang tertib administrasi pelaksanaan kegiatan, tentu melewati komunikasi pihak BPPM DIY kepada pihak pengelola P2TPA "RDU" DIY.

Yang ikut menentukan tingkat keberhasilan suatu kebijakan adalah pihak implementor mengetahui apa yang harus dilakukan dalam implementasi di lapangan. Apa yang menjadi tujuan dan sasaran kebijakan (target group) sehingga akan mengurangi distorsi implementasi. Apabila tujuan dan sasaran suatu kebijakan tidak jelas atau bahkan tidak diketahui sama sekali oleh kelompok sasaran, maka kemungkinan akan terjadi resistensi dari kelompok sasaran. Tujuan dari kegiatan yang dilaksanakan di P2TPA "RDU" adalah melayani korban kekerasan yang melapor. Sedangkan sasarannya adalah perempuan dan anak yang menjadi korban kekerasan itu sendiri. Dalam hal penyaluran informasi, tingkatan birokrasi dari pembuat kebijakan, yaitu BPPM DIY kepada implementor, yang dalam hal ini adalah pihak P2TPA "RDU" adalah bersifat langsung atau tidak terdapat banyak tingkatan birokrasi, sehingga dalam hal ini transmisi informasi mengenai tujuan dan sasaran kegiatan tidak mengalami banyak distorsi.

Sifat kejelasan dari informasi merupakan faktor yang cukup penting lainnya. Tujuan dan sasaran, serta jenis pelayanan yang harus diberikan dalam kegiatan "Pelayanan Perlindungan Perempuan dan Anak Korban Kekerasan" sendiri di sini sudah cukup jelas dan tidak ambigu, yaitu untuk melayani korban kekerasan pelapor yang datang ke P2TPA "RDU" dengan memberikan kepada mereka jenis pelayanan yang dibutuhkan oleh korban pada saat itu, sesuai dengan jenis pelayanan yang tersedia.

Dalam hal kejelasan informasi dari pembuat kebijakan kepada pihak implementor, terdapat suatu permasalahan untuk diperhatikan. Menurut hasil 
wawancara dengan salah satu pengelola P2TPA "RDU" DIY diperoleh informasi bahwa pada implementasi kegiatan di P2TPA "RDU" DIY, terdapat permasalahan yang timbul, yaitu mengenai kejelasan informasi dari arti kata "selesai"-nya suatu kasus. Di sini belum ada penjelasan yang lebih rinci mengenai arti kata selesainya kasus yang ditangani, apakah hanya sesuai dengan keinginan klien, atau terdapat syarat kelayakan yang lain, yang menyesuaikan dengan kondisi korban saat itu.

Konsistensi dari kebijakan yang harus dilaksanakan mempunyai peranan terhadap sukses atau tidaknya implementasi kegiatan "Pelayanan Perlindungan Perempuan dan Anak Korban Kekerasan". Dalam hal ini, kebijakan pemerintah tentang pelaksanaan kegiatan bersifat konsisten atau tidak berubah-ubah, sehingga implementor, yang dalam hal ini adalah pengelola P2TPA "RDU" cukup jelas dalam mengimplementasikan rencana yang ada di lapangan.

Dalam penanganan korban kekerasan perempuan dan anak di DIY, P2TPA "RDU" merupakan salah satu anggota dari Forum Penanganan Korban Kekerasan (FPKK) DIY. Aspek komunikasi yang terbentuk dalam FPKK ini juga terdapat dalam pertemuan rutin anggota forum. Pertemuan ini berjalan setiap 2 bulan sekali dimana semua anggota forum berkumpul untuk bertukar informasi dan pemikiran membahas seputar perlindungan terhadap perempuan dan anak korban kekerasan di DIY. Yang menjadi fasilitator sekaligus menganggarkan untuk keperluan rapat rutin ini adalah BPPM DIY. Komunikasi secara rutin dianggap perlu untuk tetap menyeragamkan visi dan misi anggota forum dalam upaya penanganan terhadap perempuan dan anak korban kekerasan di DIY.

Untuk komunikasi di tingkat internal P2TPA "RDU", sudah terjalin dalam proses penanganan korban yang melapor. Setelah korban melapor dan ditangani di oleh bidang layanan pengaduan, maka para kepala bidang layanan akan berkomunikasi dan berkompromi mengenai jenis layanan apa yang selanjutnya sesuai untuk korban. Apakah layanan psikologi, kesehatan, atau hukum. Selain itu juga terdapat bentuk komunikasi yang lain berupa rapat koordinasi rutin bulanan internal pengelola P2TPA "RDU" dan rapat tidak terjadwal bila ternyata kondisi mengharuskan untuk dilaksanakan.

\section{b) Sumber Daya}

Dikaitkan dengan hasil temuan di lapangan, setelah melihat Dokumen Pelaksanaan Perubahan Anggaran (DPPA) BPPM DIY untuk kegiatan "Pelayanan Perlindungan Perempuan dan Anak Korban Kekerasan" dapat diketahui bahwa tingkat pendapatan para pengurus P2TPA "RDU" sebagian besar adalah di bawah Upah Minimum Kota Yogyakarta 2014. Hal lain yang ditemukan adalah bahwa tidak setiap jam kerja, semua pengurus lengkap ada di kantor P2TPA "RDU". Disamping pekerjaannya sebagai pengurus di kantor
P2TPA "RDU", mereka biasanya mempunyai profesi lain diluar ini, walaupun jika dibutuhkan tenaganya mereka tetap hadir dan melaksanakan perannya masingmasing di P2TPA "RDU". Kesulitan tetap saja hadir jika pada saat konselor dibutuhkan tenaganya di P2TPA "RDU" untuk melakukan konseling terhadap korban, sementara ia juga ada tugas penting lainnya di saat yang bersamaan. Hal ini tentu saja menjadi salah satu faktor yang bisa membuat kinerja pelayanan menjadi kurang maksimal.

Dalam hal SDM, secara umum sudah bekerja dengan baik, walaupun dengan keterbatasan yang ada. Dengan besaran pendapatan dari kantor ini yang bisa dikatakan relatif tidak banyak, mereka bisa bekerja secara profesional dan semaksimal mungkin dalam melayani korban. Kurangnya komunikasi dalam perencanaan kegiatan antara BPPM DIY dengan P2TPA "RDU", mengakibatkan para konselor dan pendamping TESA 129 belum mendapatkan pelatihan yang sesuai dengan kebutuhan di lapangan.

Jika dikaitkan dengan penelitian yang telah dilakukan oleh Misriyani Hartati (2013) yang berjudul "Studi Tentang Upaya Penanganan Tindak Kekerasan Terhadap Perempuan dan Anak (Studi Kasus Pada Pusat Pelayanan Terpadu Pemberdayaan Perempuan dan Anak (P2TP2A) Provinsi Kalimantan Timur)", menunjukkan kepada kita bahwa dukungan sumber daya sangatlah penting untuk keberhasilan upaya penanganan terhadap korban kekerasan. Dalam hal pendanaan, sumber dana dari APBD setempat dan bantuan donatur yang ada dirasa kurang bagi operasional P2TPA Kalimantan Timur, sementara dukungan dana dari Pemerintah Daerah DIY, selama ini dirasa mencukupi untuk kebutuhan penanganan selama di P2TPA "RDU". Jika pelayanan di "RDU" dirasa kurang mencukupi kebutuhan korban, akan dirujuk kepada anggota FPKK yang mempunyai jenis layanan yang dibutuhkan. Kaitannya dengan SDM yang ada, jumlah SDM di P2TPA "RDU" DIY lebih banyak daripada jumlah P2TPA Kalimantan Timur, yaitu 15 orang tenaga teknis yang langsung menangani korban kekerasan, bila dibandingkan dengan 5 orang tenaga konselor di P2TPA Kalimantan Timur. Dari segi komitmen SDM, kedua P2TPA mempunyai petugaspetugas yang mempunyai komitmen tinggi terhadap perlindungan perempuan dan anak. Dalam hal sarana pendukung lain, kurang tersedianya sarana transportasi berupa mobil operasional merupakan kesamaan antara kedua penelitian ini. Pada kedua P2TPA juga belum memiliki fasilitas rumah aman (shelter), tetapi sudah sama-sama memiliki rumah singgah sementara (semi shelter).

Kaitannya dengan pagu anggaran, pagu saat ini dapat melayani kebutuhan korban kekerasan perempuan dan anak di P2TPA "RDU" selama satu tahun anggaran. Hal ini diketahui dari laporan pelaksanaan kegiatan 
P2TPA "RDU" di akhir tahun anggaran 2014 di BPPM DIY. Dana ini dicairkan tiga bulan sekali. Bila ternyata pagu untuk tiga bulan sekarang tidak mencukupi, dikarenakan korban yang ditangani melebihi pagu yang dianggarkan, maka keuangan akan dicover dahulu oleh BPPM DIY dan akan dimasukkan ke dalam pagu anggaran triwulan berikutnya. Hal ini terkait dengan sifat pelayanan di P2TPA "RDU", dimana jumlah korban yang dilayani dan kebutuhannya tidaklah bisa dipastikan. Untuk jenis pelayanan lain bisa dirujuk ke anggota FPKK sesuai dengan tupoksinya. Misalnya untuk kebutuhan visum bisa dirujuk ke pihak Rumah Sakit.

Sebagai salah satu perpanjangan tangan pemerintah yang beroperasi di bidang pelayanan langsung kepada masyarakat DIY, dimana lokasinya bisa saja jauh dari kota lokasi kantor berada, keberadaan sarana yang berupa mobil dinas tentu sangat diperlukan. Untuk saat ini mobil yang menjadi inventaris di P2TPA "RDU" dirasa kurang layak. Mobil yang saat ini tersedia adalah Toyota Kijang keluaran tahun 1991. Mobil ini dinilai sudah tidak layak untuk sarana operasional di P2TPA "RDU".

Dalam kaitannya dengan fasilitas untuk menunjang kegiatan TESA 129 perihal aksesibilitas panggilan, dimana telepon pada TESA 129 tidak bisa dihubungi dari nomor telepon genggam/seluler, membuat pelayanan yang ada menjadi kurang maksimal. Seperti kita ketahui bersama, bahwa pada masa sekarang, telepon genggam merupakan hal umum dan tidak sulit untuk dimiliki oleh siapa saja, termasuk oleh anak-anak. Bila telepon layanan TESA 129 tidak bisa diakses dari telepon genggam, maka akan sangat menyulitkan para user (anak-anak) untuk memanfaatkan tersedianya layanan ini. Hal ini merupakan salah satu kendala teknis yang dihadapi petugas di lapangan dalam menjalankan tugasnya.

Dengan adanya serangkaian keterangan diatas, peneliti menilai bahwa secara umum fasilitas pendukung yang ada di P2TPA "RDU" sudah cukup baik dan ikut menunjang pelayanan kepada korban. Di sisi lain masih terdapat hal-hal yang perlu dibenahi, seperti halnya mobil operasional dan aksesibilitas telepon TESA 129 dari telepon genggam. Bila permasalahan yang ada bisa teratasi, maka akan lebih meningkatkan pelayanan terhadap perempuan dan anak korban kekerasan di DIY.

\section{c) Disposisi}

Dalam hal ini, komitmen para pengurus P2TPA "RDU" sudah baik. Hal ini terlihat dari kesediaan mereka untuk ikut ambil bagian dalam tim yang bekerja menangani korban kekerasan di P2TPA "RDU", meskipun pendapatan dari sini bisa dibilang tidak besar. Selain itu juga bisa dilihat dari banyaknya kasus yang sudah mereka tangani selama ini, dengan sumber daya yang terbatas.
Dalam menangani kasus yang semakin kompleks, diperlukan pemahaman yang baik dari pihak implementor terhadap perencanaan awal dan SOP dari kegiatan yang dilakukan. Dari wawancara terhadap para narasumber yaitu para pengelola P2TPA "RDU" DIY, dapat diketahui bahwa keseriusan implementor dalam menyelesaikan suatu kasus sampai selesai adalah suatu hal yang positif. Disisi lain, penyelesaian kasus yang ada terkadang kurang sepenuhnya melibatkan fungsi jejaring FPKK yang sudah ada. Dengan adanya FPKK, seharusnya kegiatan yang tidak terdapat penganggarannya pada P2TPA "RDU", dikomunikasikan kepada anggota FPKK yang lain, dan diberikan surat rujukan penanganan kepada anggota forum tersebut.

Dari hasil wawancara dan pengamatan langsung peneliti di lapangan, bahwa secara umum, keberadaan P2TPA "RDU" sudah sangat membantu masyarakat, khususnya para korban kekerasan perempuan dan anak. Jika terjadi suatu kasus atau korban yang melapor, niat baik, komitmen, dan kerjasama diantara para pengurus sudah terbentuk. Mereka sudah bahu-membahu untuk melakukan pelayanan yang baik bagi pelanggan/korban kekerasan. Hanya saja dalam hal memaksimalkan fungsi dari jejaring FPKK perlu untuk lebih ditingkatkan lagi.

\section{d) Struktur Birokrasi}

Secara birokrasi, struktur organisasi P2TPA "RDU" sudah diatur dalam Pergub DIY Nomor 67 tahun 2012. Di sini sudah diatur mengenai ketugasan tiap-tiap unsur yang ada di P2TPA "RDU", mulai dari direktur, hingga pelaksana teknis di lapangan.

Dukungan dari pejabat berkepentingan, penguasa eksekutif maupun legislatif juga terlihat dari besarnya anggaran yang dialokasikan untuk kegiatan "Pelayanan Perlindungan Perempuan dan Anak Korban Kekerasan" yang setiap tahunnya mengalami peningkatan. Selain itu, untuk fasilitas yang menunjang pelayanan di P2TPA "RDU" sudah dilengkapi secara bertahap dari tahun ke tahun. Gedung P2TPA "RDU" yang sekarang ada adalah merupakan hasil dari pembangunan pada tahun 2013. Sebelumnya, kondisi gedung, yang juga merupakan tempat semi shelter bagi korban kekerasan, belum sebaik sekarang.

Dalam pelayanannya, P2TPA "RDU" bekerjasama dengan pihak lain dalam FPKK DIY. Kaitanya dengan hal ini, bila fungsi koordinasi bisa berjalan dengan baik, banyaknya aktor yang berperan dapat menghasilkan pelayanan yang lebih berkualitas. Sebaliknya, tanpa kerjasama yang baik antar aktor, dapat menghambat upaya pelayanan yang maksimal. Yang terjadi di lapangan secara umum adalah bahwa antar anggota forum sudah berkomunikasi dan bekerjasama dengan baik. Hal ini terlihat dari adanya rujukan dari satu anggota ke anggota yang lain bila memang korban memerlukan jenis pelayanan yang tersedia di tempat yang dirujuk tersebut. Sebagai contoh adalah pada kasus 
perujukan korban yang diwawancara oleh peneliti, dimana dia ditangani oleh P2TPA "RDU" setelah dirujuk oleh salah satu RS di Kota Yogyakarta.

Dari serangkaian keterangan yang dipaparkan diatas, dapat dikatakan bahwa untuk keadaan saat ini, unsur birokrasi yang ada sudah mendukung P2TPA "RDU" dalam upaya menjalankan tugasnya dalam pelayanan terhadap perempuan dan anak korban kekerasan. Kekurangannya adalah belum terdapat unsur ketugasan seperti halnya petugas yang mengawal kepentingan korban dari awal sampai berakhirnya kasus. Untuk pengembangan organisasi menjadi lebih besar dari yang sekarang memang harus dilakukan kajian mendalam dahulu mengenai urgensi keadaan yang sekarang dan juga kesiapan sumber daya yang ada, termasuk di dalamnya SDM dan anggaran yang tersedia.

\section{Kesimpulan}

Berdasarkan penelitian dan analisis yang telah dilakukan, penulis dapat mengambil kesimpulan bahwa:

a) Perencanaan perlindungan perempuan dan anak korban kekerasan di BPPM DIY dalam hal penyusunan RKA kegiatan Pelayanan Perlindungan Perempuan dan Anak Korban Kekerasan, jika mengacu pada syarat sebuah perencanaan yang baik menurut Darwin (2006), maka penyusunan rencana sudah sesuai dengan kaidah-kaidah yang ada, tetapi masih kurang dalam hal koordinasi dan sifat partisipatori.

b) Implementasi rencana perlindungan perempuan dan anak korban kekerasan di P2TPA "RDU" DIY secara umum sudah berjalan dengan baik, dimana jenis layanan dan mekanisme pelayanan yang ada di P2TPA "RDU" sudah sesuai dengan Peraturan Gubernur DIY Nomor 67 tahun 2012 tentang Organisasi dan Tata Kerja Pusat Pelayanan Terpadu Perempuan \& Anak Korban Kekerasan "Rekso Dyah Utami" yang digunakan sebagai acuan pelaksanaan kegiatan di P2TPA "RDU" DIY.

c) Faktor-faktor yang mempengaruhi implementasi perlindungan perempuan dan anak korban kekerasan di P2TPA "RDU" DIY adalah:

- Komunikasi, yang berupa transmisi, kejelasan, serta konsistensi informasi antara pembuat kebijakan (Pemerintah melalui BPPM DIY) dengan implementor, yaitu pihak pengelola P2TPA "RDU" sudah ada, tetapi dalam hal kejelasan informasi, masih perlu dijelaskan lagi arti kata "selesai"-nya suatu kasus. Dalam hal komunikasi diantara anggota FPKK maupun untuk komunikasi dalam internal P2TPA "RDU" DIY sudah berjalan dengan baik.

- Sumber daya, dimana secara umum SDM, anggaran, maupun sarana penunjang lainnya yang ada di P2TPA "RDU" sudah cukup baik, tetapi masih ada beberapa jenis sumber daya yang memerlukan peningkatan kualitas.

- Disposisi implementor, bahwa niat baik, komitmen, dan kerjasama diantara para pengurus sudah baik, tetapi dalam hal memaksimalkan fungsi dari jejaring FPKK perlu untuk lebih ditingkatkan lagi;

- Struktur birokrasi, dimana struktur birokrasi yang ada sudah mendukung P2TPA "RDU" dalam upaya menjalankan perannya untuk melayani perempuan dan anak korban kekerasan, hanya saja belum terdapat unsur ketugasan seperti halnya petugas yang mengawal kepentingan korban dari awal sampai berakhirnya kasus.

\section{Daftar Pustaka}

Conyers, D. \& Hills, P. (1990). An Introduction to Development Planning in The Third World. John Wiley and Sons Ltd, New York.

Gosita, A. (1993). Masalah Korban Kejahatan. Akademika Pressindo, Jakarta.

Hartati, M. (2013). Studi Tentang Upaya Penanganan Tindak Kekerasan Terhadap Perempuan dan Anak (Studi Kasus Pada Pusat Pelayanan Terpadu Pemberdayaan Perempuan dan Anak (P2TP2A) Provinsi Kalimantan Timur)). Ejournal Fisip Unmul, 1(3). 1094-1106.

Muladi. (2005). Hak Asasi Manusia, Hakekat, Konsep dan Implikasinya dalam Perspektif Hukum dan Masyarakat. Refika Aditama,Bandung.

Nashir, H. (1999). Agama dan Krisis Kemanusiaan Modern. Pustaka Pelajar, Yogyakarta.

Peraturan Gubernur DIY Nomor 67 tahun 2012 tentang Organisasi Dan Tata Kerja Pusat Pelayanan Terpadu Perempuan \& Anak Korban Kekerasan “ Rekso Dyah Utami “.

Peraturan Presiden Republik Indonesia Nomor 18 Tahun 2014 Tentang Perlindungan Dan Pemberdayaan Perempuan Dan Anak Dalam Konflik Sosial

Salusu, J. (2003). Pengambilan Keputusan Stratejik untuk Organisasi Publik dan Organisasi Non Profit. Grasindo, Jakarta.

Sitanggang, H. (1999). Perencanaan Pembangunan, Suatu Teori dan Praktik. PT Penebar Swadaya, Jakarta.

Sedarmayanti. (2004). Good Governance (Kepemerintahan Yang Baik). CV Mandar Maju, Bandung.

Subarsono, A.G. (2011). Analisis Kebijakan Publik. Pustaka Pelajar, Yogyakarta.

Suhendra, K. (2006). Peranan Birokrasi dalam Pemberdayaan Masyarakat. Alfabeta, Bandung. 
Sutrisminah, Emi. (2011). Dampak Kekerasan Pada Istri Dalam Rumah Tangga Terhadap Kesehatan Reproduksi. Jurnal Majalah Ilmiah Sultan Agung (Unissula). Semarang.

Tarigan, R. (2012). Perencanaan Pembangunan Wilayah. Bumi Aksara, Jakarta.

Tjokroamidjojo, B. (1995). Perencanaan Pembangunan. PT Toko Gunung Agung, Jakarta.

Undang-Undang Nomor 23 Tahun 2004 Tentang Penghapusan Kekerasan Dalam Rumah Tangga.

Wahab, S.A. (2008). Analisis Kebijakan Dari Formulasi Kebijaksanaan ke Implementasi Kebijakan Negara. Bumi Aksara, Jakarta.

Windu, M. (1971). Kekuasaan dan Kekerasan Menurut Johan Galtung. Kanisius, Bandung. 